\title{
Refractive Indices of Maltose Solutions
}

\author{
Emma J. McDonald
}

\begin{abstract}
The refractive indices of maltose hydrate solutions have been determined at $20^{\circ}$ and at $25^{\circ} \mathrm{C}$. Equations relating the refractive index to the percentage concentration of sugar have been prepared from the observed data by the method of averages. A table, giving the refractive indices of maltose solutions at 1-percent intervals over a range of 1 to 65 percent of maltose hydrate at both $20^{\circ}$ and $25^{\circ} \mathrm{C}$, is included.
\end{abstract}

\section{Introduction}

The disaccharide, maltose, has found extensive use in the food industry. Starch is converted into "soluble starch" by mild acid treatment, and this in turn is hydrolized to a mixture of maltose and dextrins by the enzymes of barley flour. Much of the maltose is not further purified but is used as a constituent of this mixture. Upon hydrolysis, maltose yields two glucose units, which are joined in the maltose molecule to form a 4-D-glucose Dglucoside. In the present investigation refractive index measurements have been made of aqueous maltose solutions at $20^{\circ}$ and at $25^{\circ} \mathrm{C}$. It is believed that these values will be of use in estimating the quantity of maltose present in solutions of the pure sugar, as well as in those containing maltose along with other sugars.

\section{Purification of Maltose Hydrate}

Maltose crystallizes from aqueous solution and from aqueous alcohol solution as maltose $\cdot \mathrm{H}_{2} \mathrm{O}$. Considerable care is required to remove the last traces of dextrins. The preparation of the pure sugar by crystallization from alcohol, from acetic acid $^{1}$ and by deacetylation of the acetate ${ }^{2}$ have been discussed in the literature.

The sugar used in this investigation was prepared by three recrystallizations of maltose from aqueous solution at approximately $5^{\circ} \mathrm{C}$. The starting product was the chemically pure maltose of Pfanstiehl and of Eastman Kodak Co. The sugar was dissolved in water and the solution filtered through carbon, evaporated under reduced pressure, and crystallized in an ice bath with constant stirring. After the first crystallizations the carbon was omitted. The crystals were dried at room temperature, and finally at $50^{\circ} \mathrm{C}$. They gave a very clear solution, were ash free, and had a specific rotation of +130.5 (water, $\mathrm{C}=4.73$ ). This crystallization from water solution gives lower yields than when alcohol is used but has the advantage that small amounts of dextrose or dextrins remain in solution.

1 T. S. Harding, Sugar 25, 350 (1923)

${ }^{2}$ G. Zemplén, Ber. deut, chem.59, 1258 (1926); Ber. Ges. 60, 21555 (1927); G. Zemplén and E. Pacsu, Ber, deut. chem, 62, 1613 (1929); W. A. Mitchell, J. Am Chem. Soc. 63, 3534 (1941).
The maltose used for the refractive index determinations was found to contain 0.14 percent of moisture in excess of the theoretical 5.00 percent for maltose hydrate. This moisture content was determined by a procedure used previously in this laboratory by R. F. Jackson, who found that carefully prepared maltose hydrate dried at room temperature and finally at $50^{\circ} \dot{\mathrm{C}}$ contained 5.13 percent of moisture rather than the theoretical 5.00 percent. He dried maltose to constant weight in a vacuum over $\mathrm{P}_{2} \mathrm{O}_{5}$. The initial drying temperature of $64^{\circ} \mathrm{C}$ was slowly increased to $105^{\circ} \mathrm{C}$. In order to be assured that the loss of weight, in excess of 5.0 percent, was not due to decomposition, a sample of the sugar hydrate was allowed to come to equilibrium in an atmosphere whose vapor pressure was that of pure maltose hydrate. This vapor pressure was maintained by means of a mixture containing equal amounts of maltose hydrate and partially dehydrated maltose hydrate. A relatively small sample of the sugar hydrate after standing 255 hours at $56^{\circ} \mathrm{C}$ in this environment reached a constant weight and had lost 0.13 percent of its weight.

Tables 1 and 2 record data obtained by R. F. Jackson.

TABLE 1. Drying of maltose hydrate in vacuum over $\mathrm{P}_{2} \mathrm{O}_{5}$

\begin{tabular}{|c|c|c|c|c|c|c|c|}
\hline \multicolumn{4}{|c|}{ Sample 1: $1.16355 \mathrm{~g}$, moisture $5.14 \%$} & \multicolumn{4}{|c|}{ Sample 2: $1.1093 \mathrm{~g}$, moisture $5.12 \%$} \\
\hline $\begin{array}{c}\text { Tempera- } \\
\text { ture }\end{array}$ & Time & Loss & $\begin{array}{l}\text { Total } \\
\text { loss }\end{array}$ & $\begin{array}{c}\text { Tempera- } \\
\text { ture }\end{array}$ & Time & Loss & $\begin{array}{l}\text { Total } \\
\text { loss }\end{array}$ \\
\hline $\begin{array}{c}{ }^{\circ} C \\
76 \\
76 \\
100 \\
100 \\
100\end{array}$ & $\begin{array}{c}h r \\
26 \\
19 \\
3 \\
7 \\
3\end{array}$ & $\begin{array}{r}m g \\
42.1 \\
2.3 \\
2.0 \\
1.8 \\
0.3\end{array}$ & $\begin{array}{c}m g \\
42.1 \\
44.4 \\
46.4 \\
48.2 \\
48.5\end{array}$ & $\begin{array}{r}{ }^{\circ} \mathrm{C} \\
76 \\
76 \\
100 \\
100 \\
100\end{array}$ & $\begin{array}{c}h r \\
26 \\
19 \\
3 \\
7 \\
3\end{array}$ & $\begin{array}{c}m g \\
44.1 \\
2.1 \\
1.6 \\
1.4 \\
0.5\end{array}$ & $\begin{array}{c}m g \\
44.1 \\
46.1 \\
47.8 \\
49.2 \\
49.7\end{array}$ \\
\hline $\begin{array}{l}100 \\
105 \\
105 \\
105 \\
105\end{array}$ & $\begin{array}{l}3.5 \\
4 \\
8 \\
8.2 \\
6.4\end{array}$ & $\begin{array}{r}.6 \\
2.2 \\
2.5 \\
1.7 \\
1.3\end{array}$ & $\begin{array}{l}49.1 \\
51.1 \\
53.6 \\
55.3 \\
56.6\end{array}$ & $\begin{array}{l}100 \\
110 \\
110 \\
110 \\
110\end{array}$ & $\begin{array}{l}3.5 \\
3 \\
2.2 \\
2 \\
2\end{array}$ & $\begin{array}{r}.6 \\
3.8 \\
1.9 \\
0.4 \\
.3\end{array}$ & $\begin{array}{l}50.3 \\
54.1 \\
56.0 \\
56.4 \\
56.7\end{array}$ \\
\hline $\begin{array}{l}105 \\
105 \\
105 \\
105 \\
105\end{array}$ & $\begin{array}{l}10.3 \\
6.8 \\
7.2 \\
6 \\
4\end{array}$ & $\begin{array}{l}1.8 \\
0.4 \\
.5 \\
.25 \\
.15\end{array}$ & $\begin{array}{l}58.4 \\
58.8 \\
59.3 \\
59.5 \\
59.7\end{array}$ & $\begin{array}{r}110 \\
\text { Total }\end{array}$ & $\begin{array}{c}4 \\
74.7\end{array}$ & 0 & 56.8 \\
\hline $\begin{array}{l}105 \\
105\end{array}$ & $\begin{array}{l}4.5 \\
4\end{array}$ & $0^{.1}$ & $\begin{array}{l}59.8 \\
59.8\end{array}$ & & & & \\
\hline Total & 130.9 & & & & & & \\
\hline
\end{tabular}


TABLE 2. Maltose hydrate sample in atmosphere having vapor pressure of maltose. $\mathrm{H}_{2} \mathrm{O}$

\begin{tabular}{|c|c|c|c|}
\hline Temperature & Time & Loss & Total loss \\
\hline $\begin{array}{l}{ }^{\circ} \mathrm{C} \\
36 \\
56 \\
56 \\
56 \\
54 \\
55\end{array}$ & $\begin{array}{c}h r \\
40 \\
40 \\
40 \\
45 \\
45 \\
45\end{array}$ & $\begin{array}{c}m g \\
0.65 \\
.3 \\
.1 \\
.2 \\
-.1 \\
0\end{array}$ & $\begin{array}{l}m g \\
0.65 \\
.95 \\
1.05 \\
1.25 \\
1.15 \\
1.15\end{array}$ \\
\hline Total.... & 255 & 9. $13 \%$ & \\
\hline
\end{tabular}

\section{Measurements and Discussion of Results}

The refractive index measurements were made on solutions whose concentrations varied from approximately 1 to 65 percent of maltose hydrate. All measurements were made under carefully controlled temperature conditions. Observations over the entire range of concentration were made on a Bausch \& Lomb precision refractometer, and at the lower concentrations, a Zeiss dipping refractometer was used. These instruments were calibrated at this Bureau. A measurement of the refractive index of water ${ }^{3}$ was made before and after that of each maltose solution, and proper corrections were applied. The value used was the average of four or five readings on a given solution. The maximum difference on a given solution never exceeded 0.00002 in refractive index. Each solution stood at least 4 hours to allow the maltose to reach equilibrium. ${ }^{4}$

Sixteen observations were made at $20^{\circ} \mathrm{C}$ and eight observations at $25^{\circ} \mathrm{C}$. Equations relating the refractive index to the percentage concentration of sugar hydrate $(p)$ were calculated by the method of averages from the observed data. Equations 1 and 2 express this relationship.

$$
\left.\begin{array}{r}
n_{D}^{20}=1.33299+1.38914 \times 10^{-3} p+4.7602 \times 10^{-6} p^{2} \\
+2.0933 \times 10^{-8} p^{3}-6.124 \times 10^{-11} p^{4}
\end{array}\right\}
$$

Tables 3 and 4 contain the observed data, along with the calculated values. At $20^{\circ} \mathrm{C}$ the average deviation of the calculated values from those observed amounts to \pm 0.000024 , whereas at $25^{\circ} \mathrm{C}$ the corresponding average deviation is \pm 0.000049 . At both temperatures the deviations at the higher concentrations are greater than in the lower range. This may be attributed to the increased difficulty in the preparation and the handling of the solutions of higher concentration. The refractive indices in table 5 were calculated by means of eq 1 and 2. The temperature coefficient of maltose solutions appears to be very similar to that of sucrose solutions in this temperature range. The apparent decrease in temperature effect above 44percent concentration is small and may be a result of

${ }^{3}$ L. W. Tilton and J. K. Taylor, J. Research NBS 20, 419 (1938).

${ }_{4}^{4}$ H. S. Isbell and W. W. Pigman, J. Research NBS 18, 183 (1937) R P969. experimental error. It is of the same order of magnitude as the deviation of the observed values from the calculated values. At $21^{\circ} \mathrm{C}$ a saturated maltose solution contains 46.4 percent of sugar; thus the solutions with concentration above 46.4 percent are supersaturated and are more subject to error due to shifting of the equilibrium products. It appears that a temperature coefficient of 0.00016 would be within the

\begin{tabular}{|c|c|c|c|}
\hline $\begin{array}{l}\text { Percentage } \\
\text { of maltose } \\
\text { hydrate }\end{array}$ & $\begin{array}{c}n_{D}^{20} \\
\text { (observed) }\end{array}$ & $\begin{array}{c}n_{D}^{20} \\
\text { (calculated) a }\end{array}$ & $\begin{array}{l}\text { Observed- } \\
\text { calculated }\end{array}$ \\
\hline $\begin{array}{r}1.563 \\
5.015 \\
7.003 \\
12.929\end{array}$ & $\begin{array}{l}\text { 1. } 33518 \\
\text { 1. } 34008 \\
\text { 1. } 34294 \\
\text { 1. } 35180\end{array}$ & $\begin{array}{l}\text { 1. } 33517 \\
\text { 1. } 34008 \\
\text { 1. } 34296 \\
\text { 1. } 35179\end{array}$ & $\begin{array}{r}+0.00001 \\
.00000 \\
-.00002 \\
+.00001\end{array}$ \\
\hline $\begin{array}{l}14.410 \\
20.512 \\
25.586 \\
25.197\end{array}$ & $\begin{array}{l}\text { 1. } 35404 \\
\text { 1. } 36362 \\
\text { 1. } 37200 \\
1.37135\end{array}$ & $\begin{array}{l}\text { 1. } 35406 \\
\text { 1. } 36366 \\
\text { 1. } 37197 \\
\text { 1. } 37132\end{array}$ & $\begin{array}{r}-.00002 \\
-.00004 \\
+.00003 \\
+.00003\end{array}$ \\
\hline $\begin{array}{l}31.034 \\
36.666 \\
40.995 \\
44.801\end{array}$ & $\begin{array}{l}\text { 1. } 38126 \\
1.39128 \\
1.39918 \\
1.40640\end{array}$ & $\begin{array}{l}\text { 1. } 38125 \\
\text { 1. } 39124 \\
\text { 1. } 399: 21 \\
\text { 1. } 40641\end{array}$ & $\begin{array}{r}+.00001 \\
+.00004 \\
-.00003 \\
-.00001\end{array}$ \\
\hline $\begin{array}{l}50.713 \\
55.537 \\
59.798 \\
65.529\end{array}$ & $\begin{array}{l}\text { 1. } 41807 \\
\text { 1. } 42781 \\
\text { 1. } 43674 \\
\text { 1. } 44920\end{array}$ & $\begin{array}{l}\text { 1. } 41800 \\
\text { 1. } 42782 \\
\text { 1. } 43677 \\
\text { 1. } 4492 \%\end{array}$ & $\begin{array}{l}+.00007 \\
-.00001 \\
-.00003 \\
-.00002\end{array}$ \\
\hline \multicolumn{4}{|c|}{ A verage deviation \pm 0.0000} \\
\hline
\end{tabular}
experimental error of the data for the concentration range above 23 percent.

TABLE 3. Refractive indices of maltose solutions at $20^{\circ} \mathrm{C}$

a Equation 1 was used in obtaining calculated values.

TABLE 4. Refractive indices of maltose solutions at $25^{\circ} \mathrm{C}$

\begin{tabular}{|c|c|c|c|}
\hline $\begin{array}{c}\text { Percentage } \\
\text { of maltose } \\
\text { hydrate }\end{array}$ & $\begin{array}{c}n_{D}^{25} \\
\text { (observed) }\end{array}$ & $\begin{array}{c}n_{D}^{25} \\
\text { (calculated) a }\end{array}$ & $\begin{array}{c}\text { Observed- } \\
\text { calculated }\end{array}$ \\
\cline { 1 - 1 } 3.312 & 1.33709 & 1.33712 & -0.00003 \\
10.180 & 1.34707 & 1.34703 & +.00004 \\
12.530 & 1.35051 & 1.35054 & -.00003 \\
25.530 & 1.37026 & 1.37023 & +.00003 \\
39.837 & 1.39633 & 1.39626 & +.00007 \\
40.405 & 1.39725 & 1.39732 & -.00007 \\
50.992 & 1.41777 & 1.41783 & +.00006 \\
65.551 & 1.44842 & 1.44836 & -.00006 \\
\hline \multicolumn{3}{|c|}{ Average deviation \pm 0.000049} \\
\hline \multicolumn{3}{c}{} \\
\hline
\end{tabular}

\begin{tabular}{|c|c|c|c|c|}
\hline Percent & $n_{D}^{20}$ & $n_{D}^{25}$ & $\Delta n$ & $\Delta n / \Delta t$ \\
\hline 1 & 1. 33438 & 1. 33389 & 0.00049 & 0.00010 \\
\hline $\begin{array}{l}1 \\
2\end{array}$ & 1. 33579 & 1. 33528 & .00051 & 0.00010 \\
\hline 3 & 1. 33720 & 1. 33668 & .00052 & .00010 \\
\hline 4 & 1. 33862 & 1. 33810 & .00052 & .00010 \\
\hline $\begin{array}{l} \pm \\
5\end{array}$ & 1. 34006 & 1. 33952 & .00054 & .00011 \\
\hline 6 & 1. 34150 & 1. 34095 & .00055 & .00011 \\
\hline 7 & 1. 34295 & 1. 34239 & .00056 & .00011 \\
\hline 8 & 1. 34442 & 1. 34384 & .00058 & .00012 \\
\hline 9 & 1. 34589 & 1. 34530 & .00059 & .00012 \\
\hline 10 & 1. 34738 & 1. 34677 & .00061 & .00012 \\
\hline & & & & i \\
\hline 11 & 1. 34887 & 1. 34825 & .00062 & .00012 \\
\hline 12 & 1. 35039 & 1. 34974 & .00065 & .00013 \\
\hline 13 & 1. 35190 & 1. 35124 & .00066 & .00013 \\
\hline 14 & 1. 35343 & 1. 35276 & .00067 & .00013 \\
\hline 15 & 1. 35497 & 1. 35428 & .00069 & .00014 \\
\hline
\end{tabular}

a Equation 2 was used in obtaining calculated values.

TABLE 5. Refractive indices of maltose hydrate solutions at $20^{\circ}$ and $25^{\circ} \mathrm{C}$ 
TABLE 5. Refractive indices of maltose hydrate solutions at $20^{\circ}$ and $25^{\circ} \mathrm{C}$-Continued

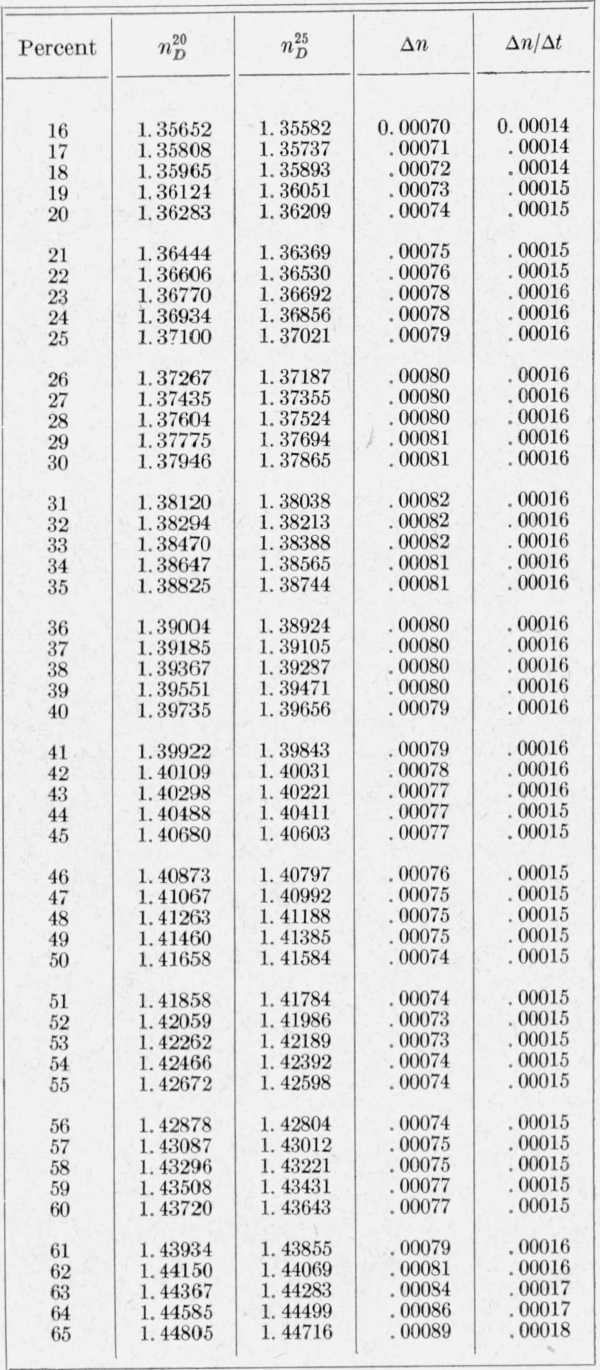

Results of work by F. W. Zerban and J. Martin, now in press (J. Assoc. Off. Agr. Chem.) on the refractive indices of maltose solutions at $20^{\circ} \mathrm{C}$ is in good agreement with the results obtained in this investigation. Previous work may be summarized as follows. Tolman and Smith ${ }^{5}$ reported the refractive indices of maltose solutions of relatively low concentrations. In their discussion they state that the sugars were dried at $70^{\circ} \mathrm{C}$ under a diminished pressure of about 27 in.; no other comment is made as to the preparation of the sugar. The following refractive indices are those reported by these authors along with values obtained from table 5 of this investigation.

\begin{tabular}{|c|c|c|}
\hline $\begin{array}{c}\text { Percentage of } \\
\text { maltose }\end{array}$ & $n_{D}^{20}(\mathrm{~T}$ and $\mathrm{S})$ & $n_{D}^{20}(\mathrm{McD})$ \\
\hline & 1.3343 & 1.3344 \\
1.00 & 1.3357 & 1.3359 \\
2.07 & 1.3402 & 1.3402 \\
5.07 & 1.3477 & 1.3475 \\
10.07 & 1.3555 & 1.3552 \\
15.12 & 1.3637 & 1.3631 \\
$20.17^{-\ldots . .-}$ & & \\
& & \\
\hline
\end{tabular}

Pulvermacher ${ }^{6}$ determined the refractive indices of maltose solutions whose concentrations varied from 1.16 to 19.40 percent of anhydrous sugar at $25^{\circ} \mathrm{C}$. His results are reported to the fourth place, and the values are all higher by one in the third place than the results here presented. As the results reported in the same article by Pulvermacher are higher for glucose than the accepted values, it appears that perhaps some discrepancy persisted throughout his measurements.

WAshington, October 23, 1950.

${ }_{5}^{5}$ L. M. Tolman and W. B. Smith, J. Am. Chem. Soc. 28, 1476 (1906). 6 G. Pulvermacher, Z. anorg. chem. 113, 141 (1920). 